\title{
Border Crossing in Contemporary Brazilian Culture: Global Perspectives from the Twenty-First Century Literary Scene ${ }^{1}$
}

\author{
Cimara Valim de Melo
}

Brasil or Brazil? The differences between Brazil seen from inside and Brazil seen from outside start with the spelling of its name. According to the Encyclopedia Britannica (2010, 487-89), Brazil is a country of South America which covers nearly half the continent's total land area and has the largest population of any Latin-American state, made of several different intermixed ethnic groups and holding the image of miscegenation of races and cultures.

Facing the variety of Brazilian arts among the contemporary Brazilian cultural history and the way it has been responding to the opening of the country to the globalisation phenomenon, we seek to investigate the process of the internationalisation of Brazilian literature in the twenty-first century, by analysing how it has broadened time-space horizons and expanded its own borders due the social and economic rise in the last decades. Thus, we start the analysis by discussing how Brazil has been affected by globalisation in the artistic field as well as how the country has been thought of and imagined by the contemporary world. Subsequently, we analyse some cases which show contemporary Brazilian literature in a broad range of perspectives but focusing on the novel as a genre. Firstly, we investigate the reception of Brazilian literature abroad by taking as a case the contemporary Brazilian novels and novelists seen from the

\footnotetext{
${ }^{1}$ I would like to thank Prof. David Treece of the Department of Arts and Humanities at King's College London, for his cooperation and suggestions as my postdoctoral supervisor. I am also very grateful to King's Brazil Institute, Seeley Library (University of Cambridge), British Library and Maugham Library (King's College London), for their support, as well as to Companhia das Letras, for the resources provided for the research. Last, special thanks to Martin John Fletcher, for the comments on an earlier draft of this article.
}

RRASILIANA- Journal for Brazilian Studies. Vol. 4, n.2 (2016). ISSN 2245-4373. 
United Kingdom's perspective. The anthology Babel Guide to Brazilian Fiction (2001); issue 121 of the Granta: Magazine of new writing, entitled The best of Young Brazilian novelists (2012); the literary festival Flipside (2013) and the anthology published at the event, called Other carnivals: new stories from Brazil are discussed in this section. Secondly, we analyse the literary market in Brazil having as a study case the project Amores Expressos [Express Loves], led by Companhia das Letras publishing house, which took Brazilian writers to different cities around the world. By observing the movement of Brazilian artists throughout the globe, the reception of Brazilian literature in the United Kingdom and the relations between art and the literary market, we intend to provoke some reflections on Brazilian cultural history in the light of the twenty-first century.

\section{Effects of globalisation in Brazil}

Brazil has been playing an important role in the global scene. Indeed, it has been affected directly by the globalisation upsurge in the 1990s, since the end of the Cold War. These international political and economic changes have collided with the process of democratisation of the country in the 1980s, which culminated in the direct election in 1989, the president's impeachment in 1991 and the emergence of democracy in the following government in Brazil. Meanwhile, the advent of the internet and other hightech devices, available on a large scale in the country from the 1990s with the boom of the new technologies worldwide, and the rise of capitalism in the world economy have changed images of time and space forever. The factors outlined above have remained the main causes for the rise of globalisation in Brazil.

Giddens (1990) defines globalisation as "the intensification of worldwide social 
relations which link distant localities in such a way that happenings are shaped by events occurring many miles away and vice versa". As a consequence of the annihilation of space, Glenn (2007) highlights the fact that that we are ever more conscious of living in a global village as globalisation brings the development of a common consciousness of human society on a world scale. The world viewed as a single place "is therefore changing the way we view that world".

Regarding contemporary globalisation, it is important to observe the phenomenon of regional integration, which happened in the 1990s affecting regional blocs and therefore raising alternatives of globalisation among countries. ${ }^{2}$ Globalisation, thereby, has been responsible for trend integration, which has raised economic interdependence and has made Latin American economies stronger. Among them, Brazil has intensified economic relations in the last decades, as well as developing high technology business, even though it hasn't solved many of the problems which affect its growth and welfare: corruption, lack of labor specialisation, under-investment in infrastructure, poverty, violence, inequality.

Renato Baumann (2008) presents some external conditions that might influence the outcome of integration exercises in Latin America in the twenty-first century. Amongst them, there is high international mobility; infrastructure themes, which must be considered if Latin America intends to sustain output growth rates; the emergence of new actors in the international scenario in the western as well as oriental world, which

2 In order to illustrate that process, we can witness the creation of many trade agreements, i.e. the European Union (1992), the South African Development Community (SADC) in 1992, the North American Free Trade Association (NAFTA), the West African Economic and Monetary Union (UEMOA) in 1994. Focusing on Latin America, we can foreground Mercosul (1991); the Andean Community of Nations (ANCOM), which replaced in 1996 the Andean Community (1969); the Latin American Integration Association (LAIA), created in 1980 to replace the former Latin American Free Trade Association (1960); and the South-American Community of Nations (CASA), formed by Mercosul and the Andean Community in 2004 and renamed as South-American Union of Nations (UNASUR) in 2007. Other representative integrations in Latin America but non-inclusive to Brazil are the Association of Caribbean States (ACS), created in 2004, and the Caribbean Community (CARICOM), formed in 1973.

RRASILIANA- Journal for Brazilian Studies. Vol. 4, n.2 (2016). ISSN 2245-4373. 
raise the perspective of a new 'polycentrism'. Moreover, nowadays Latin America faces the paths and gaps between globalisation and regionalisation. Many efforts have been made in order to strengthen the countries' economies and build regional agreements through trade integration. In the meantime, extra-regional agreements have shown the attractiveness of main markets and multilateral trade systems, exposing the face of globalisation at the expense of the outcomes of intra-regional relations. ${ }^{3}$

The way the cultures have been affected by globalisation must be considered when we look into contemporary arts. Connected to "field of cultural production" pointed out by Bourdieu (1993), cultural globalisation has as a main concept the worldwide standardisation of cultural expressions. Broadcasted by the internet, digital communication tools and the popularisation of international travel, it has been seen as a base for the understanding of the artistic market at the turn of the twenty-first century. In fact, transnational experiences should be considered as crucial factors of development of artistic production in times of globalisation. Time and space experimentation has transformed artistic representation and generated a paradox of identities, as well as problematised dichotomies such as local and global, centre and periphery.

Concerning the dichotomy 'local versus global' in a polycentric world, James Watson (2013) emphasises that the strength of local cultures calls into question the existence of an overarching global culture. The breakdown of time-space in the global

\footnotetext{
${ }^{3}$ In the case of Brazil a country which has reached the sixth position among the world's wealthiest economies (World Bank, 2013), apart from being the largest country in area and population in Latin America and the second wealthiest country in America the process of globalisation has accelerated since the 1990s due to process of democratisation, open culture, open politics and the economic growth, which has reached a peak of 7.53 per cent in GDP in 2010. Brazil has faced a notable economic slowdown recently. The GDP growth decelerated to 2.7 per cent in 2011, and reached 0.9 per cent in 2012 (Cruz, 2012). Even with a growth of 2.4 per cent (IBGE, 2013) in 2013, investment demand and industrial output have been affected by the slowdown so far. Thus, although on the one hand Brazil can be seen at the core of the process of globalisation in the twenty-first century, on the other hand it has a long road ahead in order to strengthen investment in infrastructure, cut down government costs, reduce inequalities, improve the quality of health and education and minimise some extreme regional differences.
}

RRASILIANA- Journal for Brazilian Studies. Vol. 4, n.2 (2016). ISSN 2245-4373. 
scenario has also given a range of possibilities for new experiences in the contemporary arts, which seem to follow two main routes, perhaps interconnected: the search for local aspects with regard to reconfiguration of some kind of memory and identity; and the search for global horizons through border crossing, by experiencing transits, transnational overlaps, displacement and foreignness.

Local culture remains a powerful influence in daily life. People are tied to places, and those places continue to shape particular norms and values. The fact that residents of Moscow, Beijing, and New Delhi occasionally eat at McDonald's, watch Hollywood films, and wear Nike athletic shoes (or copies thereof) does not make them "global." The appearance of homogeneity is the most salient, and ultimately the most deceptive, feature of globalization. Outward appearances do not reveal the internal meanings that people assign to a cultural innovation. True, the standardization of everyday life will likely accelerate as digital technology comes to approximate the toaster in "user-friendliness." But technological breakthroughs are not enough to create a world culture. People everywhere show a desire to partake of the fruits of globalization, but they just as earnestly want to celebrate the distinctiveness of their own cultures. (Watson, 2013)

Thereby, globalisation has widely affected Brazilian culture and the arts, not only creating standards to reach the global market, but also provoking an opposite dynamic. It has brought to light issues regarding the questioning of the country's past and present, besides individual and collective identity - recurrently raising transnational and universal issues, in a natural movement from local to global and/or from global to 
local.

Moving towards the process of cultural globalisation, Renato Ortiz states that culture is the idea-system of a world capitalist economy, as well as the consequence of the human collective and historic attempt to connect to contradictions, ambiguities, and complexities of the reality of this socio-political system. Furthermore, the mundialisation $^{4}$ of the culture corresponds to the process of globalisation lived by a territoriality, which reflects on a civilization. However, it does not mean the end of certain cultural manifestations: a 'mundialised culture' nourishes and joins other cultures (Ortiz, 1994, 26).

It has been a few decades since Brazil lost control over the borders of its literature and has entered the process of cultural 'mundialisation'. The diversity has been even more complex due to the end of the dictatorship in the 1980s and the opening of the country to the world in different fields, e.g. economics, politics, technology and culture. Nowadays, Brazilian issues have been discussed, experienced and thought about all over the world and it's no different when we think about its literature system, which has reached maturity and found its own place - not only among the country's images but also beyond national issues. Brazilian literature seems to have found a border crossing space for itself, which allows it to be seen as one of the most representative literary systems in America.

In this context, one interesting image of Brazil is given by Silviano Santiago (2005, 293), who compares the country and its literature with an amphibian due to the base of its artistic production, a "dual and antipodal ideological base". Brazil has a mixed

\footnotetext{
${ }^{4}$ Renato Ortiz's 'Globalização: notas sobre um debate' (2009) and Mundialização: saberes e crenças (2006), Jesús Martín Barbero's Globalización y multiculturalidad: notas para una agenda de investigación (1999), as well as Néstor García Canclini's La globalización imaginada (1999) and Consumers and Citizens: Globalization and Multicultural Conflicts (2001) should be considered in this context.
} 
nature; it is constituted by an amalgamation of races and cultures, a diversity of origins, colours and regions; it is made of what Gilberto Freyre (1936) called ethnic and social democracy through 'mestiçagem', carrying out throughout the century the complex process of miscegenation between a variety of indigenous, African, European and even oriental peoples. Brazilian identity, plural and open to change, seems to be crossed by many other identities, generating a net of popular and intellectual expressions. In addition, in the twenty-first century, it has been broadened, overlapping social spaces beyond the country, and connected tightly with the identity of the urban inhabitant. As Avritzer (2005) poses the issue, Brazil is formed by the public culture, which implies belonging to a pluralistic social place and, moreover, the process (and the problematic) of construction of a democratic public space. Brazil itself passed from an indecisive to a flexible and wealthy identity, growing into a giant mosaic of peoples to form a society unique in its diversity.

Contemporary Brazilian literature has given a multifaceted image of the country as well as expanding the borders of the represented world in the twenty-first century. Issues like socioeconomic challenges and citizenship have joined other ones, like the consequences of globalisation for other cultures worldwide. Propelled by the efficiency of wireless communications, international travel, and digital markets, globalisation has been seen as a trend toward homogeneity, redirecting cultural perspectives. Those social and economic changes led by the absorption of globalisation in Brazil have changed the literary scenario, as Santiago suggests $(2005,294)$ :

Traveling beyond its own national borders by means of its translation into multiple and diverse foreign idioms, the Brazilian book goes in search of new readers, ones different from those formed by decades of both legitimate and illegitimate literary practice. The amphibious character of our artistic 
production can appear - and many times does appear - less than attractive to the demanding eyes of foreign readers.

In order to look into this phenomenon in Brazil and its consequences for literature, we analyse in the following sections some examples of the process of the internationalisation of Brazilian fiction, focusing on the novel, and the reception of Brazilian literature abroad, focusing on the United Kingdom's publications.

\section{Importing Brazilian literature: three cases from the United Kingdom}

'Babel Guide to Brazilian Fiction' and the Brazilian novel on the criticism spot.

Indeed, Latin American studies have developed all over the world since the 1970s, when dictatorships dominated Latin America, changing the continental directions in different industries and exiling many artists, especially in Europe. From that period to the present, a range of publications about Brazilian literature have been produced in the English language and centres of Latin American studies have been set up in many universities, which show some evidence of the rise in the reception of Latin American culture throughout the continents. Among the bibliographical research on Brazilian literature at that time, we can find dictionaries, anthologies and guides outlining the most representative literary works for non-Brazilians interested in reviewing the literary system. Brazilian literature, by Claude L. Hulet (1974); An anthology of modern Portuguese and Brazilian prose, by A.G. de Sousa and I.R. Warner (1978); and Dictionary of Brazilian literature, by Irwin Stern (1988) can be highlighted amongst them.

In the United Kingdom, some significant works came to the forefront in the 1990s, e.g. The Cambridge history of Latin American literature (1996), by Roberto González Echevarría and Enrique Pupo-Walker, focused on Brazilian literature in its three-volume 
analysis of the extent and variety of bibliographical works in Brazil. One year before, The Babel guide to the fiction of Portugal, Brazil \& Africa in English translation was published by David Treece, Paul Hyland, Ray Keenoy and David Brookshaw, presenting a guide with a selection of the most representative of the Portuguese language literature produced in Brazil, Africa and Portugal in the twentieth century.

The publishing of two books about Brazilian literature marked the start of the twenty-first century. Brazil 2001: a revisionary history of Brazilian literature and culture, by João Cezar de Castro Rocha (2001) intended to summarise five centuries of Brazilian literature by presenting authors and their works throughout Brazilian history. The Babel guide to Brazilian fiction in English translation (Treece; Keenoy, 2001), published in the same year by David Treece and Ray Keenoy was, however, also focused on contemporary Brazilian literature, which makes it an interesting viewpoint about the reception of contemporary Brazilian literature in the United Kingdom as well as one of the first sources concerned with current Brazilian fiction.

This guide, organised by the alphabetical order of authors, is comprised of a selection of writers from the nineteenth to the twenty-first century. If we classify those selected authors by the main literary periods in Brazil, we can observe that this book emphasises the latest works and artists, which gives to the non-Brazilian readers some up-to-date perspectives on contemporary fiction. Amongst the selection of 39 artists, we can observe that 89 per cent published in the twentieth and/or twenty-first century and 32.5 per cent have important literary works published in the twenty-first century. 
Valim de Melo, Cimara. Border-Crossing in Contemporary Brazilian Culture: Global Perspectives from the TwentyFirst Century Literary Scene.

Table 1. The Babel guide for Brazilian fiction: Writers Sorted by Century of Production eighteenth century nineteenth twentieth century twenty-first century century

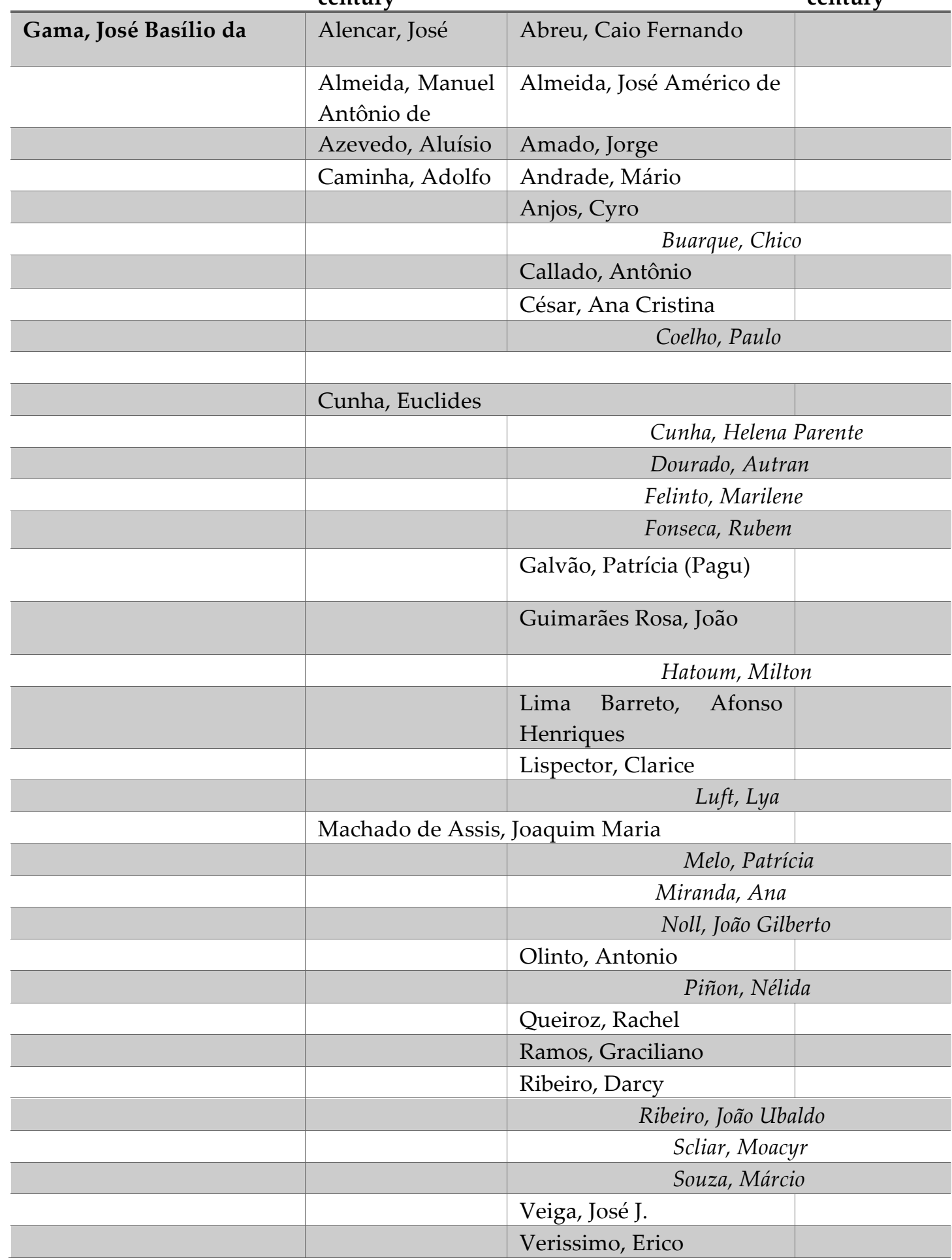

Source: author's elaboration

$3^{\text {RASILIANA- Journal for Brazilian Studies. Vol. 4, n.2 (2016). ISSN 2245-4373. }}$ 
As we can see in Table 1, all the selected authors for the Babel Guide who have published in the twenty-first century started their literary history during the second half of the twentieth century, which might show a significant connection between Brazilian social, economic and politic development and literary expression. The names in italics represent the literature of the emerging century and have a lot to say about that according to the texts and fragments chosen by Treece and Keenoy. Some examples of the way Brazilian literature has expanded its borders through fiction can be found in some of the selected authors - e.g. João Gilberto Noll, Milton Hatoum, Nélida Piñon, Patrícia Melo and Chico Buarque, respectively in the fragments from the books Hotel Atlântico, Relato de um certo oriente, A república dos sonhos, O matador and Benjamin. Indeed, all of them have discussed issues about individual and collective identities which have been recurrent in Brazilian History - as we can see in many select fragments.

'The best of Young Brazilian novelists': Granta reaches Brazilian fiction or Brazilian fiction reaches Granta's world.

Almost one century after its foundation, Granta magazine was relaunched in 1979 by a group of postgraduate students, whose thoughts and ambitions about new writing were looking at the world beyond Cambridge and the UK. Keeping the idea of 'a literary magazine with high ambitions, which would attract writers and readers well beyond the boundaries of the university', Granta has become globalised, joining names like John Freedman, from the USA, in the editorial team. Fiction has been seen like a mosaic of genres, cultures, times, spaces and viewpoints through the contemporary Granta issues, stretching the word 'literature' through a mix of reporting, travel, memoir, visual arts and fiction. "Granta did not invent this cross-fertilisation, but throughout the 1980s and 
the 1990s, it played a large part in shaping new forms of documentary story writing and creating a public appetite for them."(Granta, 2001, viii).

In recent years, Granta has acquired a global dimension, with issues in other countries and languages - there are Spanish, Brazilian, Italian, Swedish, Norwegian, Bulgarian and Chinese editions nowadays. In 2012, Granta reached Brazil. In issue 121, we can find an important facet of contemporary Brazilian fiction due to the rise of the process of internationalisation in the twenty-first century and the consequent interest in (re)discovering Brazil. The first edition of the magazine fully dedicated to Brazilian writing is centered on the 'best young novelists' in the country. The reasons for having Brazilian literature under the spotlight are given at the beginning of the Foreword:

Brazil has attracted global interest on a variety of fronts: the surging economy, sports and culture. Brazil will host the next World Cup and the 2016 Summer Olympics, and Brazilian music is as vibrant today as when bossa nova swept the world in the 1950s. Yet, when one considers literature, what is written and read in Brazil at this moment is still largely unknown outside the country. The lack of will to translate the work of our best new writers is beginning to change, and we hope that this issue will speed that momentum along. (Granta, 2012, 7).

According to Granta's viewpoint, contemporary Brazilian novelists are still deeply rooted in their experience and culture; on the other hand, the texts, which were selected for that edition, do not convey an idealised image of Brazil. Issues like time-space and identity representation come together with new cultural cartographies and ethnographies, as well as images of displacement and foreignness.

This is a generation with less interest than those that have preceded it in 
the question of a Brazilian identity. For many years this identity was often defined through a return to the land or to the 'authentic' Brazil, where the search for cultural origins could be made outside the corrupting influences of the world at large. Young Brazilian writers are not especially concerned with parsing what derives from within and what comes from outside. Sons and daughters of a nation that is more prosperous and open, they are citizens of the world, as well as Brazilians. (Granta, 2012, 7).

The authors presented within this issue were selected by a panel of judges made up of Beatriz Bracher, Italo Moriconi, Manuel da Costa Pinto, Cristóvão Tezza and Samuel Titan Jr., most of them relevant names in literary criticism circles in Brazil. Even acknowledging that the names chosen for that issue have opened some debate about the criteria for the novelists' selection, without doubt it has become a benchmark for the worldwide production and reception of contemporary Brazilian literature. Issues like urban life, inner crisis, memory, migration and foreignness are among the ones developed by the authors. The magazine has been published in Latin America, Spain, the United States, the United Kingdom and China, which reflects the important role of the media in the opening of contemporary Brazilian literature to the world.

Granta 121 provided publishing opportunities for twenty Brazilian writers, some of them well known in the Brazilian literary scene, others completely unknown as novelists. Most of them are editors at publishing houses, journalists, reporters, writers for newspapers and magazines, but we can also find visual artists and translators among the selected authors. They come from the Southeast and Southern Brazil mainly, the most developed regions in the country. São Paulo, Rio de Janeiro and Porto Alegre carry thirteen of the twenty selected authors and constitute crucial cities for the Brazilian 
literary market map. In 2012, the writers were up to forty years old and had at least one short story published (criteria for the Granta's selection).

If we follow the movement of some authors through the globe, we can observe a particularly high geographical dynamic. Firstly, we can highlight a variety of places of origin throughout the country (involving three different regions in Brazil) and abroad (Lisbon, France and Chile), which may give to the literary system a wider cultural diversity as we can see in Table 2. Secondly, their Latin American roots have been seen as an important point among the authors: Uruguayan (Miguel Del Castilho), Argentinian (Julián Fuks) and Chilean (Javier Arancibia Contreras), apart from Arabian and/or Jewish (Tatiana Salem Levy and Michel Laub).

Table 2. Brazilian Novelists through Granta's Perspective

\begin{tabular}{|c|c|c|}
\hline Writer & City and year of birth & Other main places of stay \\
\hline Michel Laub & Porto Alegre, 1973 & São Paulo \\
\hline Miguel del Castillo & Rio de Janeiro, 1987 & São Paulo \\
\hline Tatiana Salem Levy & Lisbon, 1979 & Rio de Janeiro \\
\hline Ricardo Lísias & São Paulo, 1975 & \\
\hline Carola Saavedra & Chile, 1973 & $\begin{array}{l}\text { Spain, France, Germany, Rio } \\
\text { de Janeiro }\end{array}$ \\
\hline Vanessa Barbara & São Paulo, 1982 & \\
\hline Cristhiano Aguiar & $\begin{array}{l}\text { Campina Grande (Paraíba), } \\
1981\end{array}$ & $\begin{array}{l}\text { Recife, Berlin, Olinda, São } \\
\text { Paulo, Berkeley }\end{array}$ \\
\hline Laura Erber & Rio de Janeiro, 1979 & \\
\hline Leandro Sarmatz & Porto Alegre, 1973 & São Paulo \\
\hline Julián Fuks & São Paulo, 1981 & \\
\hline Emilio Fraia & São Paulo, 1982 & \\
\hline Antonio Prata & São Paulo, 1977 & \\
\hline Antônio Kerxenesky & Porto Alegre, 1984 & \\
\hline Javier Arancibia Contreras & Salvador, 1976 & Santos (SP) \\
\hline Chico Mattoso & France, 1978 & São Paulo, Chicago \\
\hline Carol Bensimon & Porto Alegre, 1982 & \\
\hline Luisa Geisler & Canoas (RS), 1991 & Porto Alegre \\
\hline J.P. Cuenca & Rio de Janeiro, 1978 & \\
\hline Vinícius Jatobá & Rio de Janeiro, 1980 & \\
\hline
\end{tabular}

Source: author's elaboration 
In fact, this worldwide movement of writers, caused by the development of international travel since the rise of cultural globalisation, appears to have produced consequences in their sense of belonging and interpretation of time-space through narratives. Literary experiences have been created and/or developed beyond the country's borders, redefining the dichotomy 'local versus global' by reworking identities and replacing them with the border zone.

Examples of this frontier literature can be found in many contemporary Brazilian novels. Some of them are $A$ chave da casa (2007, São Paulo Prize for Literature), by Tatiana Salem Levy; Paisagem com Dromedário (2010, Rachel de Queiroz Award for best young author), by Carola Saavedra; Diário da queda (2011, Brasília Award, Bravo!/Bradesco Prize), by Michel Laub; and Procura do romance (2011, shortlisted for the São Paulo Prize for Literature), by Julián Fuks. These narratives have in common experiences of identity through transits, exile, memory and foreignness.

Flipside and 'Other carnivals, new stories from Brazil': widening the direction of Brazilian literature in the new millennium

Another important movement towards the globalisation of Brazilian culture is the event Flipside, which took place in England in October 2013. The 'Festival of Brazilian \& UK literature, music and arts' was inspired by the Festa Internacional de Paraty (FLIP), an international literary event set in Brazil each year since 2003.

[...] FLIP [...], South America's first literary festival, has drawn crowds in the tens of thousands to the tiny fishing village, and inspired similar literary festivals to spring up all over Brazil. [...] Now FLIP has given birth to Flipside, in the UK. Over the first weekend of October 2013, 12 leading Brazilian writers and musicians will light up the magical Suffolk 
marshes at Snape Maltings, and together with a select group of UK writers, all of whom have been guests of FLIP, will renew those stimulating conversations begun 10 years ago on another magical coast 8,000 miles away. (Flipside, 2013).

Flipside had Liz Calder, Genevieve Christie, Louis Baum and John Christie as organisers, and Full Circle Editions as director. The publishing house also led the publication of the book Other carnivals: new stories from Brazil (2013), launched at the event. According to the publisher, the book joined stories about Brazilian life past and present, written by "some of Brazil's finest authors from all corners of the country and ranging from well-established veterans to emerging literary stars", who subvert clichés about the country with their writing on a variety of themes and geographies and in different styles. The editor also points out both the emergence of Brazilian culture and the development of the country in the twenty-first century as reasons for the interest in its literature. In Gurría-Quintana's words $(2013,9)$, Brazil is seen by some foreigners as a country of the moment as well as a place steeped in paradox:

[...] a country whose perceived hedonism is in sharp contrast to its deep-rooted conservatism; a country whose favelas are now as iconic as its national monuments; a country that looms large over the hemisphere, yet remains culturally isolated from its Spanish-speaking neighbours; a country rippled by unrest even as it lays claim to significant social and political achievements.

A variety of issues concerning the country are looked into by the select authors' literary approaches: migration, social contrasts, poverty, violence, race, rural and urban spaces, language, foreignness. This piece of Brazilian literature translated into English can be 
seen as a sample of Flipside regarding the access of non-Brazilians to contemporary Brazilian literature. With this regard, the editor calls the reader's attention to the translation scenario by saying that the scarcity of writings translated from Portuguese into English, due to the lack of familiarity from the Anglophone audiences, may be changing. The current heightened awareness of Brazilian literature has been caused by "embattled publishers who have not lost faith in foreign authors and their Englishlanguage readers" as well as "dedicated translators", i.e. John Gledson, Margaret JullCosta and Alison Entrekin, who have been concerned with the reader as much as with the source material. Granta magazine's recent Best of young Brazilian novelists is also mentioned and responsible for having amplified the "buzz-one of the authors". (GurríaQuintana, 2013, 9).

Looking at the Brazilian writers invited to Flipside and the ones who joined Other Carnivals, we can again highlight the wealth of transits and the cultural mobility of the writers, who have been in different places and absorbed social, artistic and geographical experiences around the globe. Amongst them, at least 85 per cent have moved within Brazil, living in different states and regions; 57 per cent have lived abroad or were exiled during the dictatorship period; 43 per cent have left Latin America and have been in Europe, in countries like France, Portugal, Spain, Switzerland or the United Kingdom. Ana Maria Machado, for example, an award-winning writer who was born in Rio de Janeiro and faced exile in the dictatorship period, has lived in Paris and London, and has been writing novels since 1984, besides her vast range of publications for children. Other examples of award-winning writers can be found: Patrícia Melo, a novelist, scriptwriter and playwright, who recently won an award at the Frankfurt Book Fair, was born in Assis (SP) but lives in Switzerland; Adriana Lisboa, a novelist who was born in Rio de Janeiro, has been in France, Japan and currently lives in the USA; Milton 
Hatoum, who was born in Manaus (AM), has been in France and USA, Spain and lived in three different regions in Brazil; Cristóvão Tezza, who was born in Lages (SC), has been in Portugal; Bernardo Carvalho, who was born in Rio de Janeiro, has been in Paris and New York as the Folha de São Paulo correspondent as well as in San Petersburg as one of the selected writers for the Amores Expressos project.

Other points worth mentioning: from fourteen writers involved with Flipside and/or its publication, 6 were present at the event - Ferréz, Adriana Lisboa, Bernardo Carvalho, Patrícia Melo and Ana Maria Machado (although the two last ones were not among the selected writers for Other Carnivals). Tatiana Salem Levy, who received the São Paulo Prize for Literature with the novel A chave de casa (2007) and wrote the story 'Lost time' in Other carnivals, has also been selected by Granta 121 as one of the best young Brazilian novelists. Finally, Milton Hatoum and Patrícia Melo, important names at Flipside, had been mentioned in the English Babel guide to the Brazilian fiction in English translation twelve years before the event took place at Snape Maltings.

\section{Exporting Brazilian literature (and writers): contrasting art and literary markets through Amores Expressos}

Moving in another direction, the experience of internationalisation of Brazilian literature has also been encouraged by the Brazilian cultural market. An example of this can be seen in the Amores Expressos project, led by Rodrigo Teixeira, and promoted by Companhia das Letras, one of the most important publishing houses in Brazil. Amores Expressos invited seventeen writers to spend around one month in a pre-selected city around the world. As forecasted project results, each writer should produce an unedited writing set in the chosen city, having 'love' as a theme. The literary works would be published by Companhia das Letras and perhaps adapted later for the cinema. 
From seventeen authors who faced the challenge and took part in the project, ten have had their works published by Companhia das Letras from 2008 to 2013. André de Leones had his writing published in 2010 by Rocco, another important publishing house in Brazil. ${ }^{5}$ However, Adriana Lisboa, Antonia Pellegrino, Antonio Prata, Cecilia Gianetti, Lourenço Mutarelli and Reinaldo Moraes who traveled respectively to Paris, Bombay, Shanghai, Berlin, New York and Mexico City, haven't had their writings finished and/or published yet. The list of published books can been seen in Table 3 .

Table 3. Books by 'Amores Expressos' Series

\begin{tabular}{|l|l|l|}
\hline Title & Author & Visited city \\
\hline Barreira (2013) & Amilcar Bettega Barbosa & Istambul \\
\hline $\begin{array}{l}\text { Digam a Satã que o recado foi } \\
\text { entendido (2013) }\end{array}$ & Daniel Pellizzari & Dublin \\
\hline $\begin{array}{l}\text { Ithaca Road (2013 } \\
\text { O livro de Praga: narrativas } \\
\text { de amor e arte (2011) }\end{array}$ & Paulo Scott & Sérgio Sant'Anna \\
\hline Nunca vai embora (2011) & Chico Mattoso & Prague \\
\hline $\begin{array}{l}\text { O único final feliz para uma } \\
\text { história de amor é um acidente } \\
\text { (2010) }\end{array}$ & João Paulo Cuenca & Havana \\
\hline $\begin{array}{l}\text { Do fundo do poço se vê a lua } \\
\text { (2010) }\end{array}$ & Joca Reiners Terron & Tóquio \\
\hline $\begin{array}{l}\text { Estive em Lisboa e lembrei de } \\
\text { você (2009) }\end{array}$ & Luiz Ruffato & Cairo \\
\hline $\begin{array}{l}\text { O filho da mãe (2009) } \\
\text { Cordilheira (2008) }\end{array}$ & Bernardo Carvalho & Lisbon \\
\hline $\begin{array}{l}\text { Como desaparecer } \\
\text { completamente (2010)* }\end{array}$ & Daniel Galera & Saint Pertersburg \\
\hline
\end{tabular}

*Published by Rocco

Source: author's elaboration

The authors' trips happened during 2007, and they were expected to finish the writing by one year after the intercultural experience. Nevertheless, the project results have just 
been seen over the following six years. Such a daring project has provoked contrasting responses from some of the selected writers who could not finish and/or publish their works. ${ }^{6}$ Reinaldo Moraes explained to Folha that one of the reasons for the delay was the fact of being commissioned literature. After he had been in Mexico City, he tried to finish the writing but problems in the plot made him abandon it. Meanwhile, he had other literary works, one of which is Pornopopeia (2009). "I was trapped with the idea of being literature on demand. I think literature is a kind of sacred temple", he said. "I will only accept book on demand requests again if I am starving" (apud Almeida, 2013b). Another issue is regarding Adriana Lisboa's work. One of the most expressive contemporary Brazilian novelists in the twenty-first century, Lisboa finished the writing of the book in 2008, although it hasn't been published yet. According to the author, the story placed in Paris has had structural problems, which made her leave it aside. In the meantime, she published Azul corvo (2010) and Hanói (2013), both raising issues about displacement, border crossing and identity.

On the other hand, this project seems to have contributed to the internationalization of some authors and their works worldwide. Novels like Cordilheira (2008, Biblioteca Nacional Award), by Daniel Galera; and O filho da mãe (2009, a finalist for The São Paulo Literature Prize), and Estive em Lisboa e lembrei de você (2009, a finalist for The São Paulo Literature Prize) have been shortlisted/awarded in Brazil and translated into different languages. Mattoso and Cuenca were included in Granta 121 (2012). Carvalho, Lisboa and Moraes were among the selected writers for Other Carnivals (2013), and the first two joined the event Flipside as invited writers. Galera and Scott were among the invited speakers at Edinburgh International Book Festival 2014.

\footnotetext{
${ }^{6}$ Available at: http://www1.folha.uol.com.br/ilustrada/2013/07/1317373-encomenda-travou-escritores-da-colecaoamores-expressos.shtml, presents authors who haven't had theirs works published or concluded yet.
} 
The case Amores Expressos provides the analysis of the connections and contrasts between literature and the cultural market, art and product. Whereas literature has been seen as product rather than art in the contemporary word, it's not possible to disconnect it from its aesthetic and critical roots within the artistic field. Although, on the one hand, Companhia das Letras has focused on literature on demand through the Amores Expressos project, on the other hand it has created innovative possibilities for the authors to experience literature in different time-spaces around the world, which have produced favourable results for the internationalisation of Brazilian literature.

\section{Conclusions}

Investigating literature and the contemporary arts scene can appear as if we were penetrating a misty field. There is no literary canon to be followed or questioned; there are just writings which have been produced and writers who have been consolidated within the literary system, who might be seen later - or not - as the most representative authors in the literature of that time-space. Indeed, if we look into contemporary Brazilian literature, we can infer that it has been moving into a global literary system rather than being fed by a local group of authors, readers and literary works. Meanwhile, Brazilian literature itself has become increasingly concerned with global issues, by amplifying time and space representation and projecting language and aesthetics beyond the country's borders without ceasing to be Brazilian literature. More dynamic and seeking to represent the contemporary world's diversity and paradoxes, it has absorbed issues connected to displacement, identity, social and cultural borders.

The dynamism of contemporary spaces is caused by permanent urban mobility, represented continuously by current Brazilian novels, which is constituted by imprecise 
spatiality, bridging the gaps between apparently far away regions and making the limits between reality and fiction even more diffuse. These movements involve crossings, displacement, replacement, migratory flows, through which there is the contact between different urban complexities [...].

[...] The current Brazilian novel is on the border between times and spaces. It carries the city's contradictions without forgetting the countryside. It focuses on different moments of past and present, looking to get specific aspects of individual and collective life rather than panoramic views of an age. It is configured by authors and writings spread over different regions in Brazil, going beyond local frontiers in order to problematise universal themes. (Melo, 2013, 307308, translated from Portuguese).

There are many reasons for this dynamism within literature in the twenty-first century. Some novels refer to the country's political and economic opening since its democratisation process in the 1980s as well as its social development in the two last decades. Others are associated with the effects of cultural globalisation and the high technology development mainly from the 1990s: the rise of access to authors' writings through new media and digital reading tools; the increasing amount of Brazilian literature translated into English; the development and popularisation of airline companies in Brazil and the consequent ease of world travel by authors. Furthermore, Brazilian writers have commonly moved to different regions, countries and continents, some of them becoming globe trotters.

Drawing a comparison between the movements of Brazilian novelists in the early of twentieth century and nowadays, we can see a very different scenario, which raises 
some questions regarding socio-economic, cultural and political issues over the last century. Journeys between regions in Brazil represent the reality of 58 per cent of the writers, mainly across the South, South-East and North-East, forming three cores of literary production at the time. From the ones who traveled abroad, 80 per cent had political or academic reasons for migrating. Graciliano Ramos and Jorge Amado, writers chased out and exiled in the Getúlio Vargas government period, traveled to Europe and the USSR. Jorge Amado was also exiled in Argentina and Uruguay. Another example is Erico Verissimo, who lived in the USA as a professor at Berkeley University, in California and has also been in Mexico, and who represents a particular case among the authors. If we contrast the Brazilian fiction scene in the early twentieth and twenty-first century, we can see deep changes in the literary system, mainly in the context in which the novel has been produced and received.

Brazil has changed drastically in the last decades, opening its doors to the world in all ranges of industry. Consequently, it has provoked different citizenship perspectives in contrast to Brazil's past and present imagery. Some of these images are given by literature, through its aesthetics and time-space engenderment. In Lehen's words $(2013,2)$, the prominence of the issue of citizenship and social disparity in Brazil since 1985 is reflected in the country's recent literary production.

Looking at the results obtained from the four cases analyzed throughout the research, we can observe tendencies for current Brazilian literature and how it has been seen through the lenses of the international literary market. Contemporary fiction has been produced by a variety of authors of different ages, roots, regions, and cultural experiences. They are mainly journalists, translators, artists or editors who have been connected to the global world through the internet and experienced geographic displacement. They are writers from a diversity of origins and races, who were born in 
the 1950s, 1960s and 1970s and experienced important political changes in Brazil, like the dictatorship and the democratisation process. Most of them have written novels and short stories, belong to the middle social class and are mixed race or white. Many of them have had books translated into English in recent years in publishing houses like Bloomsbury, Boulevard Books, Full Circles, Canongate, Tagus, Texas Tech University Press, William Heinemann and/or other ones.

Among this mosaic of writers, we highlight some recurrent names which are shown in bold in Table 4. Adriana Lisboa, Chico Mattoso, João Paulo Cuenca, Antonio Prata and Tatiana Salem Levy are among the youngest generation, consisting of writers born in the 1970s. Bernardo Carvalho, Milton Hatoum, Patrícia Melo and Reinaldo Moraes are among the mature generation, formed by authors born in the 1950s and 1960s. An important facet of contemporary Brazilian literature can be seen through their literary works, which mostly consist of narrative, especially novels.

Table 4. Comparison of Selected Authors from the Case Studies

\begin{tabular}{|c|c|c|c|}
\hline 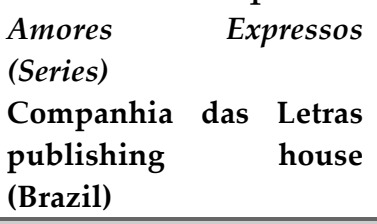 & $\begin{array}{l}\text { The Babel Guide to the } \\
\text { Brazilian fiction in } \\
\text { English translation } \\
\text { Boulevard Books (UK) }\end{array}$ & $\begin{array}{l}\text { Granta 21: The best of } \\
\text { young } \quad \text { Brazilian } \\
\text { novelists } \\
\text { Granta Publications } \\
\text { (UK, USA) }\end{array}$ & $\begin{array}{l}\text { Flipside and Other } \\
\text { Carnivals: new stories } \\
\text { from Brazil } \\
\text { Full Circle Editions } \\
\text { (UK) }\end{array}$ \\
\hline $\begin{array}{l}\text { Amilcar } \\
\text { Barbosa }\end{array}$ & Chico Buarque & Michel Laub & Ana Maria Machado \\
\hline Daniel Pellizzari & Paulo Coelho & Miguel del Castillo & Patrícia Melo \\
\hline Paulo Scott & $\begin{array}{l}\text { Helena Parente } \\
\text { Cunha }\end{array}$ & Tatiana Salem Levy & Milton Hatoum \\
\hline Sérgio Sant'Anna & Autran Dourado & Ricardo Lísias & Bernardo Carvalho \\
\hline Chico Mattoso & Marilene Felinto & Carola Saavedra & Tatiana Salem Levy \\
\hline João Paulo Cuenca & Rubem Fonseca & Vanessa Barbara & Cristóvão Tezza \\
\hline Joca Reiners Terron & Milton Hatoum & Cristhiano Aguiar & Beatriz Bracher \\
\hline Luiz Ruffato & Lya Luft & Laura Erber & Andréa del Fuego \\
\hline Bernardo Carvalho & Patrícia Melo & Leandro Sarmatz & Marcelino Freire \\
\hline Daniel Galera & Ana Miranda & Julián Fuks & Ferréz \\
\hline André de Leones* & João Gilberto Noll & Emilio Fraia & $\begin{array}{l}\text { João Anzanello } \\
\text { Carrascoza }\end{array}$ \\
\hline Adriana Lisboa** & Nélida Piñon & Antonio Prata & André Sant'Anna \\
\hline
\end{tabular}


Valim de Melo, Cimara. Border-Crossing in Contemporary Brazilian Culture: Global Perspectives from the TwentyFirst Century Literary Scene.

\begin{tabular}{|l|l|l|l}
\hline Antonia Pellegrino** & João Ubaldo Ribeiro & Antônio Kerxenesky & Adriana Lisboa \\
\hline Antonio Prata** & Moacyr Scliar & $\begin{array}{l}\text { Javier Arancibia } \\
\text { Contreras }\end{array}$ & Reinaldo Moraes \\
\hline Cecilia Gianetti** & Márcio Souza & Chico Mattoso & \\
\hline Lourenço Mutarelli** & & Carol Bensimon & \\
\hline Reinaldo Moraes** & & Luisa Geisler & \\
\hline & & João Paulo Cuenca & \\
\hline & Vinícius Jatobá & \\
\hline
\end{tabular}

${ }^{*}$ He was selected to the series by Companhia das Letras but had his writing published in 2010 by Rocco.

** Authors selected to the series by Companhia das Letras but without publications related to that at the moment.

Source: author's elaboration

Based on the information collected from those four discussed cases, Brazilian literature seen overseas has been overviewed, with its main contemporary writers and works. By understanding the effects of globalisation in Brazil in the last decades, mainly for arts and culture, we can point out as an outcome a comprehensive review of the directions taken by Brazilian literature in the twenty-first century. Along the trajectory of this research, we have produced an up-to-date panorama of how Brazilian literature has been developed in and outside Brazil, what novelists and novels have been represented, the best fiction in the country nowadays and how the novel has been seen by the literary market. Considering the results of this piece of research, we are able to look into the most representative Brazilian writers' works in order to determine the impact of cultural globalisation on contemporary literature in Brazil as well as the impact of that to the global literary system. Brazilian literature has been changing not only the image it projects to the world, but mainly the image of the world reflected back onto itself in the new millennium. What is apparent in each one of these literary facets is the incentive for new research.

3RASILIANA- Journal for Brazilian Studies. Vol. 4, n.2 (2016). ISSN 2245-4373. 


\section{References}

Almeida, Marco R. Série Amores Expressos rende mais três livros e ‘DR' sobre limites da literatura por demanda. Folha de São Paulo. 27 jul. 2013, accessed September 10, 2013, http://www1.folha.uol.com.br/ilustrada/2013/07/1317371-serie-amores-expressos-rendemais-3-livros-e-dr-sobre-limites-da-literatura-por-demanda.shtml.

Almeida, Marco R. Encomenda travou escritores da coleção Amores Expressos. Folha de São Paulo, 27 jul. 2013b, accessed September 10, 2013, $<$ http://www1.folha.uol.com.br/ilustrada/2013/07/1317373-encomenda-travou-escritoresda-colecao-amores-expressos.shtml.

Avritzer, Leonardo. Culture, Democracy, and the Formation of the Public Space in Brazil. In: Souza, Jessé; Sinder, Walter (Ed.). Imagining Brazil. Plymouth: Lexington Books, 2005.

Baumann, Renato. Integration in Latin America: Trends and Challenge. In: Economic Commission for Latin America and the Caribbean (ECLAC), 2008, accessed December 10, 2013, http://www.iadb.org/intal/intalcdi/PE/2008/01306.pdf.

Cruz, Adriana Inhudes Gonçalves et al. A economia brasileira: conquistas dos últimos anos e perspectivas para o futuro. In: Sousa, Filipe Lage (Ed.). BNDES 60 anos: perspectivas setoriais Rio De Janeiro: BNDES, 2012, accessed December 10, 2013, http://www.bndes.gov.br/SiteBNDES/export/sites/default/bndes_pt/Galerias/Arquivos/c onhecimento/livro60anos_perspectivas_setoriais/Setorial60anos_VOL1EconomiaBrasilei ra.pdf.

Echevarría, Roberto González; Pupo-Walke, Enrique. Brazilian Literature; Bibliographies. In: __. The Cambridge History of Latin American Literature, edited by Cambridge: Cambridge University Press, 1996.

Encyclopedia Britannica. Brazil. In: The New Encyclopedia Britannica. London; Chicago, 2010, V.1.

Flipside. Flipside: A Festival of Brazilian Literature, Music and Arts (Programme Booklet). Full Circle Editions: Suffolk, 2013, accessed September 20, 2013, http://www.flipsidefestival.co.uk/default.aspx.

Freyre, Gilberto. Sobrados e mucambos. São Paulo: Companhia Editora Nacional, 1936.

$3^{\text {RASILIANA- Journal for Brazilian Studies. Vol. 4, n.2 (2016). ISSN 2245-4373. }}$ 
Giddens, Anthony. The Consequences of Modernity. Cambridge: Polity Press 1990.

Glenn, John. Globalization: North-South Perspectives. Oxon: Routledge, 2007.

Granta. Twenty-One: The Best of Granta Magazine. London; New York: Granta Publications, 2001.

Granta. Granta 121: The Best of Young Brazilian Novelists. London; New York: Granta Publications, 2012.

Gurría-Quintana, Ángel (Ed.). Other Carnivals: New Stories from Brazil. Full Circle Editions: Suffolk, 2013.

IBGE. PIB cai 0,5\% em relação ao 2ํㅡ tri de 2013 e chega a $R$ \$ 1,2 trilhão. Rio De Janeiro, 2013, accessed December 12, 2013, http://saladeimprensa.ibge.gov.br/noticias?view=noticia\&id=1\&busca=1\&idnoticia=2529.

Lehen, Leila. Citizenship and Crisis in Contemporary Brazilian Literature. New York: Palgrave Macmillan, 2013.

Melo, Cimara Valim de. O lugar do romance na literatura brasileira contemporânea. São Paulo: Annablume, 2013.

Ortiz, Renato. Mundialização e cultura. São Paulo: Braziliense, 1994.

Santiago, Silviano. An Amphibious Literature. In: Souza, Jessé; Sinder, Walter (Ed.). Imagining Brazil. Plymouth: Lexington Books, 2005.

Treece, David; Keenoy. The Babel Guide to Brazilian Fiction in English Translation. London: Boulevard, 2001.

Watson, James L. Cultural Globalization. Encyclopedia Britannica, [2013], accessed December 13, 2013, http://www.britannica.com/ebchecked/topic/1357503/culturalglobalization.

World Bank. Brazil Overview. Brasília, 2013, accessed December 3, 2013, http://www.worldbank.org/en/country/brazil/overview. 